\section{References}

1. Gubareva E. A., Sotnichenko A. S., Kuevda E. V. Immunologicheskaya characteristika decellularizatsii pischevoda nizchego primate. Sovremennie problemi nauki i obrazovaniya. - Modern problems science and educations. 2015;2(2):780.

2. Gubareva E. A., Sjöqvist S., Sotnichenko A. S. Decellularizatsiya pischevoda nizchich primatov. Geni $i$ kletki - Genes \& Cells. 2014;9(4):64-69.

3. Atala A. Tissue engineering, stem cells and cloning: current concepts and changing trends. 2005.

4. Badylak S. F. The extracellular matrix as a biologic scaffold material Biomaterials. 2007;28(25):3587-3593.

5. Badylak S. F., Taylor D., Uygun K. Whole-organ tissue engineering: decellularization and recellularization of three-dimensional matrix scaffolds. Annual review of biomedical engineering. 2011:13:27-53.

6. Crapo P. M., Gilbert T. W., Badylak S. F. An overview of tissue and whole organ decellularization processes. Biomaterials. 2011;32(12):3233-3243.

7. Ruifrok A. C. Johnston D. A. Quantification of histochemical staining by color deconvolution. Analytical and quantitative cytology and histology. The International Academy of Cytology [and] American Society of Cytology. 2001;23(4):291-299.

8. Sjöqvist S., Jungebluth P., Lim M. L. Experimental orthotopic transplantation of a tissue-engineered oesophagus in rats. Nature communications. 2014;5:3562

\title{
About authors:
}

Sotnichenko Alexander, research fellow at the laboratory of fundamental research in the field of regenerative medicine, teaching assistant of the pathologic anatomy department; tel.: +7962851-82-37; e-mail: alex24.88@mail.ru

Gubareva Elena, cms, Head of the laboratory of fundamental research in the field of regenerative medicine, docent at the general and clinical pathology department; tel.: +79181327857; e-mail: g_lena82@list.ru

Gilevich Irina, postgraduated student at the department of oncology with a course of thoracic surgery;

tel.: +79183227556; e-mail: giliv@list.ru

Orlov Sergey, dms, Director of Research Institute of Medical Primatology;

tel.: +79186034838; e-mail: orloff-sv@mail.ru

Macchiarini Paolo, MD, PhD, Megagrant leading scientist, Head of the International research, clinical and educational Center of Regenerative Medicine, Krasnodar; Advanced Center for Translational regenerative Medicine, Karolinska Institute;

e-mail: paolo.macchiarini@ki.se

\section{PATHOPHYSIOLOGICAL MECHANISMS BEHIND EXPERIMENTAL ODONTOGENIC MAXILLITIS}

\author{
Koshel I. V., Shchetinin E. V., Sirak S. V.
}

Stavropol State Medical University, Russian Federation

\section{ПАТОФИЗИОАОГИЧЕСКИЕ МЕХАНИЗМЫ ЭКСПЕРИМЕНТААЬНОГО ОАОНТОГЕННОГО ВЕРХНЕЧЕАЮСТНОГО СИНУСИТА}

\author{
И. В. Кошель, Е. В. Щетинин, С. В. Сирак
}

\section{Ставропольский госуАарственный МеАицинский университет, Российская ФеАерация}

This item offers a view on the outcomes of an experimental study involving an animal model, while the study was aimed at clarifying the clinical and morphological changes taking place in the maxillary tissues in case of odontogenic inflammation. The experiment was carried out on 30 guinea-pigs, where each of these had its right-side maxillary sinus as experimental, while the left side was observed as control. The simulated odontogenic infection focus in maxillary paradontium tissues was shown to cause purulent inflammation in the paranasal sinuses on the two sides, both in the intact and in the sensibilized animals, while in the sensibilized ones the pathology in the mucosa resulted in cyst-like formation development.

Key words: maxillary sinus, mucosa, odontogenic sinusitis

В статье представлены результаты экспериментального исследования на животных по уточнению характера клинико-морфологических изменений в тканях верхнечелюстного синуса при воспалительном процессе одонтогенной этиологии. Эксперименты проведены на 30 морских свинках, у каждой из которых правая верхнечелюстная пазуха являлась опытной, а левая использовалась в качестве контроля. Установлено, что экспериментально смоделированный очаг одонтогенной инфекции в тканях пародонта верхней челюсти вызывает гнойные воспалительные процессы в придаточных пазухах носа с обеих сторон как у интактных, так и у сенсибилизированных животных, причем у сенсибилизированных животных патологический процесс в слизистой оболочке приводит к формированию кистоподобных образований.

Ключевые слова: верхнечелюстной синус, слизистая оболочка, одонтогенный синусит 
$\mathrm{T}$ he vast majority of both Russian and foreign scientists view odontogenic maxillitis (odontogenic maxillary sinusitis) as a result of an infection process penetrating, through periapical tissues, via lymphogenic, hematogenic or contact way to maxillary sinus mucosa $[1,3,13]$. The key factor facilitating the progress of the infection is considered to lie within the close proximity between the maxillary teeth root apexes and the maxillary antrum bottom (Fig. 1). Besides, there is nothing excluding another mechanism behind the pathology development in the maxillary antrum - under an impact from a focal odontogenic infection [8, 11, 12]. A number of aut hors believe that an odontogenic focus around the maxillary antrum bottom may cause acute perifocal maxillary sinusitis $[2,5,6]$.

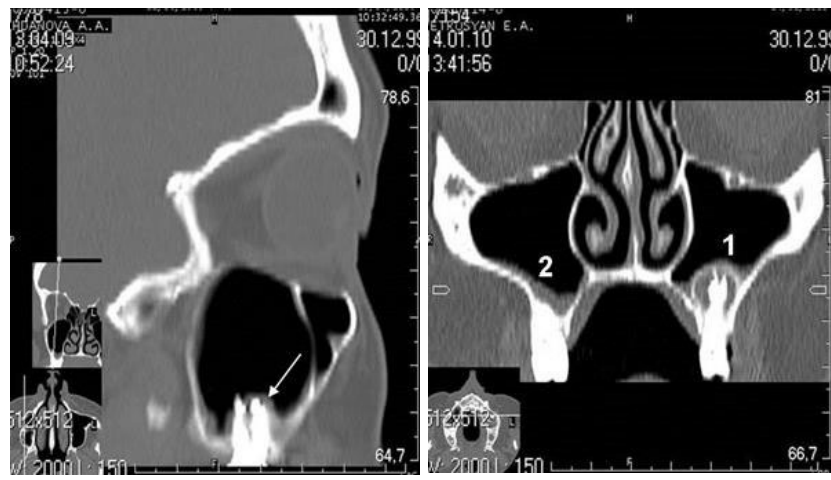

Fig. 1. CT image. Left: root apices (36 th tooth) penetrating the maxillary sinus (indicated with arrow); right - odontogenic cyst penetrating the left maxillary sinus (1), mucosal hypertrophy and edema in the right-side maxillary sinus at the spot contacting with the root apex of the periodontic tooth (2)

Other experts think that the cases of odontogenic maxillitis may be mostly chronic as the exudates accumulating in the sinus cavity might act as a non-specific stimulant and allergen that can lead to sensibilization in the body as well as in the maxillary sinus cavity mucosa, thus depleting the local immune responses $[7,9]$. In case of aggravated inflammation, two pathogenic factors may join the process at once - the infection source (contamination of sensibilized mucosa from the odontogenic focus - the root canal of the periodontic tooth) and the general body sensibilization [1, 10, 14]. During that, some pathophysiological mechanisms behind the progress of infectious odontogenic maxillary sinusitis, including the stages where inflammation involves the sinus mucosa, remain unclear and should be studied further.

Aim of study: clarifying the nature of clinical and morphological changes taking place in the maxillary sinus tissues in case of inflammation of odontogenic etiology.

Material and Methods. The research were carried out on 30 guinea-pigs (age $-2-3$ yrs) in order to achieve the aim as specified above. The choice of guinea-pig maxillary sinus as an experimental model was due to the specific anatomic and topographic features in its structure, namely lack of the front wall in these animals (which is also the case with rabbits), which offers a much easier surgical approach to the sinus mucosa. The experiment included 3 series of trials: Series 1 sensibilization of the animals with a staphylococcal allergen (the laboratory strain of Staphylococcus aureus G1908); Series 2 - developing an odontogenic infection focus in intact animals along with studying the maxillary sinus tissues from the experimental and the control sides of the maxilla; Series 3 - developing odontogenic infection focus in sensibilized animals with the same tissues investigated. The experiment was done on 30 guinea-pigs, each of these having the right maxillary sinus as experimental, whereas their left sinuses were controls. For morphological study, the mucosa from the maxillary sinus was taken, which was fixed in $10 \%$ neutral buffered formalin for three days followed with dehydratation through alcohols of ascending density, flushing, embedding in celloidine, and obtaining of extra-thin serial sections in a Malex microtome (A. Dole, 2010). The sections were stained with hematoxylin and eosin by Mallori.

In Series 1 (10 animals) the sensibilization was conducted through staphylococcal allergen injected intradermally subject to the following mode - Injections 1 and $2-3$ skin doses per each; Injections 3 and $4-4$ skin doses each; Injection 5 - 5 doses. The interval in-between the injections -4 days. Stable hyperemia detected at the injection spot was considered as sensibilization onset. The animals were taken out of the experiment on the day of the next allergen injection and 20 days after the sensibilization was over.

Series 2 (10 animals) involved the crown trepanation of the $1^{\text {st }}$ maxillary grinding tooth (the roots of which stand closest to the maxillary sinus), while after the vital pulpectomy the tooth cavity was left uncovered.

In Series 3 (10 animals), the sensibilization was performed with the staphylococcal allergen followed with (on Day 10) tooth trepanation subject to the method employed in Series 2. The animals were taken out of the experiment with ether overdose on Days 5, 10, 20, and 45 after the tooth trepanation.

All the surgeries were performed under general anesthesia (Zoletil 50); the experiment involving animals was carried out subject to the principles of reasonable laboratory practice (National Standard PRINCIPLES OF REASONABLE LABORATORY PRACTICE GOST R 534342009) and an approval from the Ethical Committee, Stavropol State Agrarian University (SSAU, № 34, of March 12, 2014)

The obtained experimental data were processed employing methods of variation statistics and Student's t-test using the software package of medical statistics Microsoft Excel 2007, Statistica for Windows 5.0. The results are presented as the arithmetic mean value and its standard error $(\mathrm{M} \pm \mathrm{m})$.

Results. A histological analysis of the material of Group 1 showed that by Day 5 after sensibilization the epithelium in the paranasal sinuses mucosa revealed an elevated number of goblet cells. The sub-epithelial zone showed mild edema and dilated lymphatic clefts, sharp vein congestion, cell infiltration composed of lymphocytes, histiocytes, and plasmatic cells (Fig. 2a). By Day 10 there was nasal serous discharge. By Day 20 the discharge increased and became of purulent type. Microscopically, the epithelium at that stage manifested some areas of destruction in the epithelial layer; in the sub-epithelial layer - abundant cell infiltration containing leukocytes, macrophages, histiocytes, and plasmatic cells. Local hemorrhages were detected as well. Therefore, there was catarrhal-desquamative maxillary sinusitis developing with a clearly defined hemorrhagic component. 

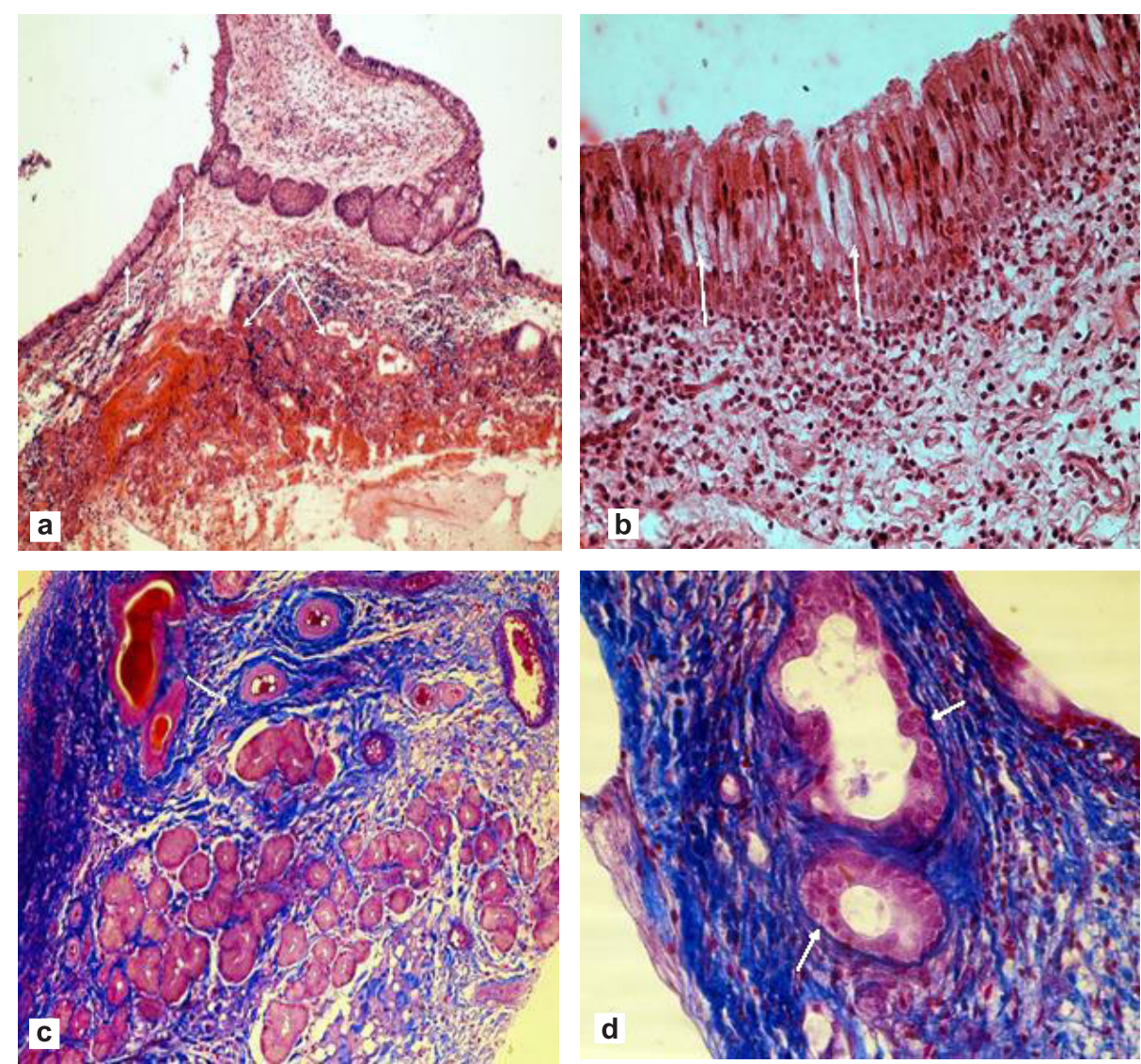

Fig. 2. Microslides, 5 (1), 10 (2), 20 (3), and 45 (4) days into the experiment. First (1), second (2) and third $(3,4)$ Series: a - increased number of goblet cells (single-line arrows), mild edema, congestion, cell infiltration in the sub-epithelial layer (double-line arrows). Hematoxylin and

eosin staining. Obj. 10, oc. 10; b - local swelling in the epithelium basal membrane, mild hyperemia, stromal edema, destruction and desquamation areas in epithelial layer (indicated with arrows). Hematoxylin and eosin staining. Obj. 10, oc. 20; c - hyperemia and infiltration of sub-epithelial layer and inter-glandular stroma with cells of lymphohistiocytic type (indicated with arrows). Staining by Mallori. Obj.10, oc. 20; d - development of false cyst-like formations (indicated with arrows). Staining by Mallori. Obj. 10, oc. 20
The number of the goblet cells in the epithelium would go up along with an increasing edema in the connective tissue stroma and its infiltration with histiocytes, plasmatic cells, and lymphocytes containing a slight presence of leukocytes.

By Day 45 the left nasal passage (control side) had some serous-purulent discharge. The right (experimental) maxillary sinus manifested some purulent mass. Microscopically, the mucosa of the sinus on the side of the devitalized tooth manifested increased numbers of goblet cells, dilated microvasculature vessels with edema of all the mucosa layers, heavy infiltration of the glandular connective tissue with lymphoid cells. The excretory ducts of mucosa glands were dilated and full of secretion. The changes observed in the maxillary sinus mucosa on the opposite (control) side, too, match the presentation typical of purulent sinusitis.

Thus, in case of uncovered pulpcavity, along with periodontitis there is also combined inflammation developing in the adjacent maxillary sinus mucosa; it first reveals itself on the affected side (5 days), while by Day 10 the maxillary sinus on the opposite (control) side gets involved, too. The inflammation turns proliferative by Day 45 simultaneously impacting both maxillary sides.

By Day 45 into sensibilization, the inflammatory processes in the maxillary sinuses went on increasing, while the nasal discharge turned clearly purulent. No microflora was detected during bacterioscopy of the smears. A microscopic study showed that epithelium manifested a significant increase in the number of goblet cells, ulceration areas with thick infiltration of the subjacent tissues with leukocytes, plasmatic cells, and macrophages. The microvasculature vessels were dilated with thick cell infiltration around them, containing leukocytes, which is typical of purulent-desquamative inflammation of maxillary sinuses.

Therefore, body sensibilization with staphylococcal allergen is an active factor provoking the onset of maxillary sinusitis. No convincing data were obtained that would prove the microbial factor's decisive role in aggravating the process.

In Series 2, by Day 5 the maxillary sinus mucosa revealed mild vascular response with perivascular agglomeration of lymphocytes, which was more prominent on the experimental (right) side. By Day 10 there was sharp focal swelling in the epithelial basal membrane, mild hyperemia, stromal edema, as well as areas of destruction and desquamation in the epithelial layer (Fig. 2b). A similar manifestation was to be observed in the maxillary sinus mucosa on the opposite (control) side.

By Day 20, both the experimental and the control maxillary sides revealed increase in the inflammation.
In Series 3, on Day 5 after the vital pulpectomy, the mucosa in the maxillary sinuses, on both sides, revealed a vascular response manifested as hyperemia, and macrophages and lymphocytes accumulation. By Day 10 there was serous-purulent nasal discharge detected; the autopsy showed that the animals' left nasal part as well as the maxillary sinuses contained purulent matter. A microscopic study of the mucosa in the right (experimental) maxillary sinus showed that the epithelium had an increase in the number of goblet cells that were heavily loaded with mucus, and that some of them had their nuclei in the state of pycnosis. The epithelial layer had numerous intraepithelial cysts.

By Day 20 the mucosa in the maxillary sinuses located on the opposite (control) side revealed deficiencies in the epithelial layer with inflammatory response from stromal cells. The loose edematous sub-epithelial tissue was found to contain lymphoid infiltrates. The sub-epithelial layer and the inter-glandular stroma were subject to intense hyperemia and infiltrated with a large amount of lymphohistiocytic cells (Fig. 2c).

By Day 45 after the vital pulpectomy, the acute inflammatory reactions ceased down and the microscopic presentation was getting the features typical of chronic inflammation. At the same time, the most prominent pathological changes were observed in the mucosa of the paranasal sinuses located closest to the devitalized tooth, and milder ones - on the opposite (control) side 
of the maxilla. The pathological process involves also the bone tissue of the maxillary sinus bottom, which comes along with the bone loss (Table) and the development of false cyst-like formations (Fig. 2d).

Morphometric analysis of the bone tissue in the maxillary sinus bottom, experimental side of maxilla, Series 3 of the experiment

\begin{tabular}{|l|c|c|c|c|}
\hline \multicolumn{1}{|c|}{$\begin{array}{c}\text { Quantitative } \\
\text { criteria, \% }\end{array}$} & \multicolumn{4}{|c|}{ Observation period, days } \\
\cline { 2 - 5 } & 5 & 10 & 20 & 45 \\
\hline $\begin{array}{l}\text { Volume of trabecular } \\
\text { bone }\end{array}$ & 28.2 & 23.7 & $18.9 *$ & $7.8^{*}$ \\
\hline $\begin{array}{l}\text { General resorption } \\
\text { surface }\end{array}$ & 13.2 & 23.9 & $11.5^{*}$ & $14.8^{* *}$ \\
\hline $\begin{array}{l}\text { Osteoclastic resorption } \\
\text { surface }\end{array}$ & $11.3^{* *}$ & 13.7 & $14.6 * *$ & $28.9 * *$ \\
\hline
\end{tabular}

Note: * the figures are reliable compared to the indicators for the control side in the animals through Series 2 of the experiment; $p<0.05 ;{ }^{* *}$ the figures are reliable compared to the indicators for the experimental side in the animals through Series 2 of the experiment; $p<0.05$.

Therefore, focal odontogenic infection coming against previous sensibilization of animals, results in bilateral

\section{References}

1. Bravo Cordero G., Minzer Ferrer S., Fernández L. Odontogenic sinusitis, oro-antral fistula and surgical repair by Bichat's fat pad: Literature review. Acta Otorrinolaringologica Espanola. 2016;67(2):107-113. doi: $10.1016 /$ j.otorri.2015.03.001

2. Brook I. Sinusitis of odontogenic origin. Otolaryngology Head and Neck Surgery, 2006;135(3):349-355. doi: 10.1016/j.otohns.2005.10.059

3. Grigoryanz L. A., Sirak S. V., Zekeryaev R. S. Pokazaniya effektivnost ispolzovaniya razlichnich hirurgicheskih vmeshatelstv pri lechenii bolnich s odontogennim gaimoritom. Stomatologia - Dentistry. 2007;86(3):42-46.

4. Grimm W. D., Dannan A., Giesenhagen B. Translational research: palatal-derived ecto-mesenchymal stem cells from human palate: a new hope for alveolar bone and cranio-facial bone reconstruction. International Journal of Stem Cells. 2014:7(1):23-29.

5. Grimm W.-D., Ploger M., Schau I. Complex, three-dimensional reconstruction of critical size defects following delayed implant placement using stem cell-containing subepithelial connective tissue graft and allogenic human bone blocks for horizontal alveolar bone augmentation: a case report as proof of clinical study principles. Medical news of North Caucasus. 2014:9(2):131133. doi: $10.14300 / \mathrm{mnnc} .2014 .09037$

6. Grimm W. D., Plöger M., Schau I. Prefabricated 3d allogenic bone block in conjunction with stem cell-containing subepithelial connective tissue graft for horizontal alveolar bone augmentation: a case report as proof of clinical study principles. Medical news of North Caucasus. 2014;9(2):175-178. doi: 10.14300/mnnc.2014.09050

7. Longhini A. B., Branstetter B. F., Ferguson B. J. Otolaryngologists' perceptions of odontogenic maxillary si- inflammation, which culminates in its chronic course with intraepithelial cysts developing (starting on Day 5 of the experiment).

Conclusions. As a result of sensibilization with staphylococcal allergen, the paranasal sinuses in the guinea-pigs developed patho-morphological changes which, in their nature, are similar to those to be seen in the maxillary sinuses accompanying odontogenic maxillitis as well as in case of nasal polyps in patients with non-isolated allergic rhinosinusopathy [4]. The odontogenic infection focus simulated in the maxillary paradontium tissues causes purulent inflammation in the paranasal sinuses on both sides, both in intact and in sensibilized animals, whereas in the sensibilized animals the pathology in the mucosa resulted in the development of false cyst-like formations.

Acknowledgments. The research work was carried out as part of the Public Task from Ministry of Healthcare of Russian Federation for scientific research and development within the area of Studying Regeneration Mechanisms using Newer Bio-Engineering Constructions based on Autologous Mesenchymal Stem Cells \& Matrix Materials of Various Origin, together with the All-Russian Research Institute of Sheep and Goat Breeding and the Stavropol State Agrarian University. nusitis. Laryngoscope. 2012; 122 (9): 1910-1914. doi: 10.1002/lary.23427

8. Mikhalchenko D. V., Poroshin A. V., Mikhalchenko V. F. Influence of transcranial electrostimulation on the osseointegration of dental implant in the experiment. Research Journal of Pharmaceutical, Biological and Chemical Sciences. 2014:5(5):705-711.

9. Sirak S. V., Sirak A. G. Morfofunkcionalnie izmeneniya $\checkmark$ pulpe zubov eksperimentalnich zhivotnich pri lechenii glubokogo kariesa i ostrogo ochagovogo pulpita. Sovremennye problemy nauki i obrazovanija - Modern problems of science and education. 2013;2:44.

10. Sirak S. V., Sletov A. A., Loktionova M. V. Diagnostika, lechenie I profilaktika verhnechelustnogo sinusita, voznikayuschego posle endodonticheskich vmeshatelstv. Parodontologiya - Parodontology. 2008;3:14-18.

11. Sirak S. V., Ibragimov I. M. Kodzokov B A Sposob subantralnoy augmentacii kosti dlya ustanovki dentalnoich implantatov pri atrofii alveolyarnogo otrostka verchney chelusti / Patent RUS 2469675, 09.11.2011.

12. Sirak S. V., Shchetinin E. V., Sletov A. A. Subantralnaya augmentaciya poristim titanom $v$ eksperimente i klinike. Stomatologiya - Dentistry. 2016;95(1):55-58.

13. Sirak S. V., Avanesyan R. A., Akkalaev A. B. Microbiocenosis of oral cavity in patients with dental implants and over-dentures. Research Journal of Pharmaceutical, Biological and Chemical Sciences. 2014:5(5):698-704.

14. Sirak S. V., Arutyunov A. V., Shchetinin E. V. Clinical and morphological substantiation of treatment of odontogenic cysts of the maxilla. Research Journal of Pharmaceutical, Biological and Chemical Sciences. 2014;5(5):682690 .

\section{About authors:}

Koshel Ivan, MD, cms, Associate Professor, Department of Othorhinolaryngology; tel.: +7(8652)350551; e-mail: koshel1979@mail.ru

Shchetinin Evgeny, MD, PhD, Head of Department for Pathological Physiology; tel.: +7(8652)35-26-84; e-mail: ev.cliph@rambler.ru

Sirak Sergey, MD, PhD, Professor, Head of Department for Dentistry; tel.: +7(8652)35-05-51; e-mail: sergejsirak@yandex.ru 